\title{
Translating the Untranslatable: Challenges, Sticking Points and Struggles
}

Sandugash Sabyrzhanovna Mukhtarova, ${ }^{+*}$ Balgenzhe Karagulova, '̇arina Sideshova, ${ }^{\dagger}$ Sabyrzhan Mukhtarov, ${ }^{\uparrow}$ Aliya Yergazina ${ }^{\uparrow}$ and Ilshat Nasipov ${ }^{\dagger}$

\section{Abstract}

The existence of any nation depends on worldwide communication. In the era of globalisation, translation practices have become even more essential. In the context of communication, cultural translation has always been necessary but little is known as to how untranslatable can be made translatable. From this perspective, this research is a timely addition to the science of translation. Translation demand increases from year to year and so is demand for a general review of papers regarding the role and place of untranslatables in translation. This research aims to present a comparative analysis of Kazakhstani writings and their Russian and English translations. Results show that transliteration is the primary way to translate general ethnographic realia into Russian. The second translation method that is often used is the equivalent translation (using words with meanings that are similar to the meanings of the original words). Additionally, translators may create a calque or new words and phrases. Results obtained can be useful when searching for the most suitable translation options.

Keywords: Translation; Culturally Bound Items; Ethnic-Specific Culture; Cultural Linguistics; Literary Translation; Context; Translation Difficulties; Lexical Gap.

\footnotetext{
${ }^{+}$M.Akmullah Bashkir State Pedagogical University

${ }^{*}$ Corresponding Author, Email: sandugash.mukhtarova.84@bk.ru, Sandymukhtarova@mail.ru

İ.Zhubanov Aqtobe Regional State University

î S.Baishev Aqtobe University

(C) 2019 Sandugash et al. This is an Open Access article distributed under the terms of the Creative Commons Attribution License (http://creativecommons.org/licenses/by/2.0), which permits unrestricted use, distribution, and reproduction in any medium, provided the original work is properly cited.
} 


\section{Introduction}

It has been about half a century since nations knew of each other's existence. With science and technology, the gap between the nations have narrowed. People now have easy access to learn about the nations better without leaving the house. This opened an opportunity for finding common interests, unique goals, and fun words. The art of translation began to develop to ensure mutual understanding between nationalities in communication (Al-Rikaby et al., 2018; Geisinger, 1994; Bassnett, 2013).

The translation is a link between nations, between languages, between pieces of literature (Lefevere, 2016). The translation is a transfer of thoughts (oral, written) from one language to another (Meylaerts, 2010). The existence of any nation depends on worldwide communication. In the era of globalisation, translation practices become even more essential. Thus, translation and its evolution path are considered from this perspective (Cronin, 2013).

In the context of communication, cultural translation has always been paramount and warrants special attention as little is known challenges posed while trying to translate the untranslatable (Davier \& Van Doorslaer, 2018). When people read about another nation, they form an opinion regarding it. Thus, a translator has to preserve the cultural peculiarities of another nation in translation (Mukhtarova, 2017).

The purpose of this research is to determine ways of localising (expressing the sense of) culture-specific items of Kazakh language in Russian and English translations. This research aims at familiarising the readers with various views on cultural translation. In doing so, it tries to examine the functional and semantic studies tackling untranslatables and provide an opportunity for a more in-depth study of lexemes that can be found in Kazakh-language works of art. The findings analyse a collection of culturally bound words found in I. Yesenberlin's historical trilogy The Nomads. The theoretical and methodological framework underpinning the research are discussed in the following sections.

\section{Theoretical and Methodological Framework}

The language is closely related to the human spirit. The first man to capture cultural peculiarities of the language in the linguistic theory was Wilhelm Von Humbolt, who lived in the second half of the XVIII and the early XIX centuries. He believed that every language is the result of the linguistic consciousness of people. Hence, the role of language cannot be understood without delving into the inner life of the nation, into the national spirit.

The term 'ethnic-specific culture' is a combination of two concepts. The first one is the word "ethnos", which is a historically consolidated community of people, such as tribes, peoples, and nations (cite the reference). Ethnic stereotypes are rooted in national memory and passed on in the form of folklore, epos, and literature (Abildinova, 2015; Bahnova, 2017). As Khaidar writes:

Thinking of Kazakh people as of an ethnic group is not an act of deride but an attempt to analyse the long and winding path of its [group's] development retrospectively, to recognise Kazakh people as an ethnicity (Khaidar, 1998: 190).

The second component of the term is the word 'culture', which came from the Middle French 'colere' meaning 'to till' as in 'till the ground". In Kazakh, the word meaning culture is 'madeniet'. It formed from the Arabic word 'madaniyat', which means 'city' or refers to something that is 'urban'. In Europe, the word 'culture' is referred to as the act of 'giving education', 'development', and 'respect'. Culture is regarded as the primary adaptive mechanism outpacing human biological evolution. From this perspective, cultural change is a process in which culture is adapting to itself (Kroeber \& Kluckhohn, 1952).

The relationship between language and ethnicity draws attention since old time (Kurkebaev, 2013). Language is tied to culture - the first 
develop within the second and defines it. Maslova notes that cultural linguistics is based on this assumption. Cultural linguistics became a separate area of linguistics in the 90 s of the twentieth century. Maslova defines this term as follows:

Cultural linguistics is a branch of linguistics that emerged as a combination of linguistics and cultural studies. It explores the relationship between language and culture in ethnic groups (Maslova, 2001: 208).

According to B. Karagulova, cultural linguistics is aimed at defining what makes the national language national. The facts and traces of national culture and values are found in the literary language and folklore. This rings true for the Kazakh culture (Karagulova et al., 2016).

According to Mankeeva (2008: 356):

contemporary linguistics encompasses a wider range of issues associated with language as a spiritual and cultural treasure of a people. The reason behind this phenomenon is simple: each language is a semiotic system that comprises history, culture, knowledge and needs, temper and conscience, the art of craft and customs. Within this system, language performs not only a communicative function but also captures culture-specific information and unites people with it.

This observation proves the association between language and culture (Mankeeva, 2008), which is further buttressed by (Atabaeva, 2006: 234):

The grasp of truth behind the ethnos can be found in [a] material and spiritual culture that has been taking its shape for centuries. This truth is commonly delivered through facts.

In translation and interpreting studies, linguistic items encompass not only facts but also categories of facts, such as geographical terms and concepts. These items are classified as untranslatables. Vereshchagin and Kostomarov (1980) note that culturally bound items have no equivalents in other cultures and other languages. Hence, they are considered specific to a particular culture and a particular language used in that particular culture (Vereshchagin and Kostomarov, 1980).

These culturally bound items are grouped into categories, the existence of which results in the emergence of lexical gaps or lacunes. Translators are accustomed to the existence of these 'holes' and perceive them as a regular part of any translation practice.

A lexical gap or lacuna is the absence of a name or a concept in a particular language. The prerequisites of socio-political and socioeconomic life of a people, its worldview, psychology, and customs are a good ground for the emergence of new notions (Kopylenko, 1995).

The culturally bound items or realia are used in a direct sense to name an object, an everyday event, a spiritual, historical and social phenomenon peculiar to a specific people or a specific country. In translation, culturally bound items pose a challenge.

In the Glossary of Linguistic Terms compiled by O.S. Akhmanova, linguistic realia has the following definitions:

- Realia is the object of study in external linguistics. It consists of various information regarding institutions, history and culture of a particular people, language bonds between native speakers.

- Realia are objects of material culture (Akhmanova, 2004).

Vlahov and Florin (2006) believe that the translation of realia balances between transcribing and making the word fit with the context.

Levy sees the translation of realia as a challenge. By contrast, Fedorov (2002:213) is convinced that "there are no words that cannot be translated into another language", assuming that any word can be replaced by a local or an international one (Fedorov, 2002:214). 
Researchers give the following definitions associated with culture-specific items:

- 'untranslatables' - words that do not have equivalents in other languages (Fedorov, 2002);

- 'exotic vocabulary' - lexical units denoting geographical and historical terms and concepts (Fedorov, 2002);

- 'lexical gap' - items that are found in one language, but are absent in other languages;

- 'foreignism' - something that allows expressing the authentic side of a particular nation, its traditions, life and habits;

- 'culturally bound items', 'culturally bound lexemes' - units of lexical meaning that characterise the features of a particular ethnic society;

- 'alienism' - words from obscure languages that illustrate the stylistic function of exoticism.

Some linguists do not use the term 'culturally bound item' or 'culture-specific item' as an equivalent to the term 'realia', which has a more specific meaning. Definitions from earlier imply that realia words denote elements of a foreign culture, with a national, historical or local ring and no equivalents in other languages and cultures. Realia are generally the language units.

Bulgarian translators, Vlakhov and Florin(2006) coined the full definition of realia words, according to which realia are:

words (and composed expressions) of the popular language representing denominations of objects, concepts, typical phenomena of a given geographic place, of material life or of socialhistorical peculiarities of some people, nation, country, tribe, that for this reason carry a national, local or historical colour; these words do not have exact matches in other languages (Vlahov and Florin, 2006: 448).

The word 'realia' is Latin for 'real things'. Initially a plural adjective, the word becomes a noun in the context of Russian and Bulgarian lexical categories. In philological texts, realia are words expressing material elements that are close in meaning to the word 'emir' meaning 'life'.

However, Fedorov regards realia words as original elements of life: "It means only a local phenomenon that cannot be found in everyday life and understanding of other people" (Fedorov, 2002:416).

The words containing realia include culturespecific items or:

- Lexical units, which are absent in the target language or have analogous but not exact equivalents. The list of culturespecific items often includes realia words that temporarily have no equivalents and unique culturally-bound words.

- Realia words also denote regional phenomena and concepts without any matches in a receiving language (Repin, 1970).

By comparing realia words used in different cultures, one can notice the following features of usage:

- The word containing realia may be completely absent in the target language: the term 'Дәріхана-дәмхана' meaning 'pharmacy-café' has no Russian equivalent.

The realia word can have a related word in another language. In this case, it provides an additional meaning.

- The American word "cloverleaf" has a Kazakh analogue 'жоңышқа жапырағы';

In different societies, similar elements of being are embodied through different realia.

- The words and concepts may be different but related: for example, people around the world have beliefs that a cuckoo bird can answer questions, but those questions differ between nations. In America, girls wonder about the time when they get married. In Russia, people are concerned with the years left to live. Thus, the term 'cuckoo's call' has different shades of meaning. 
The realia points to an interesting lexical layer of the language. This semantisation is a crucial element in learning a foreign language because realia words usually hinder the understanding of foreign words.

At this point, translators started a dispute on strategies for translating culture-specific words, given the difficulties that arise in translation.

To translate realia, the translator must pass on the spice and soul of language. This can be done in several ways. Vinogradov (2001) notes five common strategies for translating realia:

- Transcribing;

- Replacing the word with a hyponym;

- Making the word consistent with the target culture;

- Disclosing the meaning of the word;

- Creating a calque, or borrowing a word or phrase from another language while translating its components, so as creating a new lexeme in the target language (Vinogradov, 2001).

Vlahov and Florin (2006) provide a wide range of possibilities for translating realia:

- Transcribing (that is, copying) the word, character by character;

- Transcribing according to the target language's pronunciation rules;

- Creating a new word or a calque;

- Creating a new word, analogous to the original one, but which has a more local ring to it;

- Using a different but related word from the source language, passing it off as the original word;

- Making the meaning explicit;

- Replacing the word with a similar, local one;

- Replacing the word with one that is more generic or international;

- Adding an adjective to help the reader identify the origin of the element of realia;

- Translating the overall meaning.

By classification, basic solutions are transcribing, creating new words, phrases or calques, replacing words, substituting words in equivalence, and making the meaning fit with the context.

Transliteration or transcription is applied when discussing foreign names, places, names of various companies, firms, ships, newspapers, and journals (Venuti, 2017). This is the process of representing the source text (mainly, proper names, toponyms, and scientific terms) in another script format (Vinogradov, 2001).

A well-done and error-free transcript carries both the meaning and the national ring of the word. The unique sounds in the source language that do not match the sounds in the target language are written as a combination of sounds that provide the desired effect.

Transliteration is primarily concerned with representing the characters, while transcription maps the sounds (rephrase for clarity). The possibilities of transliterating realia are limited and bonded to transliteration rules. Incorrect reading or incorrect conversion of some letters can lead to severe misunderstandings (Agorni, 2016). Currently, transliteration and transcription are used less frequently in fiction than before because they do not carry the meaning of the word and challenge readers, who do not know a foreign language.

New words are created in different ways. They may be borrowed from another language with morphemes maintained but replaced by those of the native language. This process is called calquing (Barkhudarov, 1975). Another way to create a new word is to alter the original meaning of a word, which is already in the target language, but this solution is rarely used.

The last three solutions can be placed between two extremes: adequacy (closeness to the original, when the translation is accomplished word for word) and contextuality (making the word fit with the context).

When explaining the meaning of the word or by making this meaning explicit, translators must be aware of phenomena and objects that characterise the life of other people and know the meaning of a particular word. The periphrasis is often combined with transcription 
to reach a natural and close-to-the-original translation.

The translation is the only way to communicate across languages. Its main goal is to enable people speaking different languages to communicate using one language. However, translators try to use equivalents or various translation methods when translating them. To choose the right way of translating realia, the translator must know and remember the purpose of translation - to preserve the national ring of the source text, without changing the meaning of original words.

A multi-faced history of Kazakh people still has sides to explore. Many facts were twisted during the Soviet time, and they become the blank spots in the history of the nation. However, the most relevant aspects of life remained with time.

Ilyas Yesenberlin (2014; 2015) occupied a special place not only in the Kazakh literature but also in the history of the people. There are several reasons for why this happened. He wrote about the heroic path of Kazakh people in the struggle for independence and freedom. The writer embraced different sides of people's lives, creating unique images of great leaders and commanders. His historical trilogy 'The Nomads' is the best work in his collection of classic fiction. The work spread across the world in several reeditions and was translated into many languages. This trilogy can be called the "encyclopedia of life of the Kazakh Khanate."

The Kazakh vocabulary contains mainly the ethnic-specific words that pass on not only the history but also the spiritual and material heritage.

Language is part of national heritage, a tool for giving information regarding the environment and life values of people, who speak it. The ethnic groups possessed good knowledge and leaned toward lofty thoughts and ways. Thus, clothing names and production process mattered. This is why the first matter to address in translations will be the names of Kazakh national clothes.

From the look of a woman's headdress, one could form an opinion regarding her age and marital status. In the summer, girls wore multicoloured round skullcaps, known as tubeteika hats, made of silk and velvet with a flat top. The standard material for such a hat was the otter fur. The most expensive type of headdress was the bride's hat called saukele. This was a fancy tall pointed hat, decorated with precious stones. Elderly married women wear a hood made of white cloth, with no rich decoration. The hood had a hole for the face called kimeshek. In The Nomads, a reader can meet any type of headdress from earlier.

For example,

- Әсіресе Рабиу-Сұлтан-Бегімдей емес, қолына ұстаған найзасы, басына киген меруертпен торлаған қызыл барқыт сәукелесі, астындағы ақ боз аттың кекіліне таққан үкісі, бұның жауынгер елден шыққан әйел екенін көрсетеді (Yesenberlin, 2014:75).

- В отличuе om красавицы Рабиасултан-бегим, ее седло, чепрак и все остальное было украшено лишь чеканным серебром, но именно серебро шло к ее степной красоте и cmamu (Yesenberlin, 2015:40).

- Unlike those of the beautiful RabiaSultan-Begum her saddle, shabrack and the rest of the harness were only adorned with chased silver, which especially suited her steppe beauty and physique (Yesenberlin, 2015: 102).

In both translations, the word 'saukele' was excluded from the part "...басына киген меруертпен торлаған қызыл барқыт сәукелесі". This inhibited the full understanding of the hat's purpose and kept from the reader the knowledge of a woman's blood status.

- Хан шақыруынан қатты сезіктенген Жәнібек, бешпетінің ішінен қорасан болатын жұқа етіп тоқылған шағын сауыт киді (Yesenberlin, 2014:69).

- A под охотничий халат надел Джаныбек тонкую, из крепких железных нитей кольчугу, остро заточил меч и вставил новые перья в стрелы... (Yesenberlin, 2015:91). 
- And beneath his hunting gown, Janybek was wearing a thin iron-chained armour, sharp-edged sword and newly-feathered arrows... (Yesenberlin, 2015: 226).

Clearly, one can see that the word 'beshpent' was translated into Russian as 'охотничий xasam' that literally means 'a hunting robe'. In English translation, the term is a 'hunting gown'. Yet, the meaning of the word was not disclosed completely. Kazakh beshpent or beshmet is an outer garment. Moreover, Kazakhs think of a 'robe' as of something that a Kazakh woman would wear indoors, while 'beshpent' is a men's everyday clothing. Coming back to the English equivalent of the word, a 'gown' is a long, usually formal dress for a woman.

- Кереге қанат қыранға томаға кигізіп, алтыбақанда әткеншек тепкізіп, ат үстіндегі қимылға үйреткен (Yesenberlin, 2014:255).

- На голову гордой птице надевали кожаный колпак - томагу и сажали ее на качели, чтобы привыкла она к конной езде (Yesenberlin, 2015:300).

- They would put on a leather hood, tomagu, on the head of a proud bird and settle it on a swing for it to get accustomed to riding on horseback (Yesenberlin, 2015:202).

Looking closely at the word 'tomaga', which is a leather hood is put on an eagle's eyes to blind it. One can see that the translator used two strategies of translation here: transliteration and descriptive translation (material of the hood was specified within the text). However, translations carry a mispurpose of the hood. In the Kazakh language, tomaga is used to blind a hunting bird, but in translations, it serves as a headgear.

The word 'altybakan' is culturally specific. To translate the word, translators replaced it with a hypernym.

- Құндыз жағалы, қысқа лұқпан шапан, бастарында қимаш бөрік, сырттарынан қимылымызға жеңіл болсын деп кереге көз торлы сауыт киген (Yesenberlin, 2014:85).
- В легкие охотничьи кафтаны с собольей оторочкой были одеты Джаныбек с Кереем, на головах казахские шапки (Yesenberlin, 2015:51).

- Janybek and Kerei were wearing light hunting caftans trimmed with sable, Kazakh caps on their heads (Yesenberlin, 2015:134).

The words 'shapan' (a long, loose overcoat with long sleeves, lined with a layer of wool or cotton wool), 'sauyt' (a kind of combat clothing for protecting the body), and 'borik' are also culturally specific. By combining these words, translators created phrases such as 'охотничьи кафтаны' and 'light hunting caftans'. Thus, the reader will learn not only the name of the article but also its appearance. However, this combination changed the meaning of the sentence. In the original, sauyt is put on over clothing, but this was not mentioned in the translation. The meaning of the word 'borik' was simplified to a typical headdress, whereas Kazakhs have many words for different kinds of a headgear, such as 'borik' (a warm, round cap trimmed with otter, marten or raccoon fur), 'malahai' (type of fur hat, with four flaps that cover the ears, neck \& forehead, worn by men in winter), etc.

Another example is in this sentence:

- Аңшылар азығы деп түйеге саба-саба қымыз артқан, жеңіл шатырлар тиелен, алдарында он бестей қой айдаған бір топ жігіт ауылдан шыққан кезде, хан жасағы да солтүстікке қарай бей алды (Yesenberlin, 2014:208).

- Вместе с огромным караваном, груженным бурдюками с кумысом и всякими другими припасами, двинулся хан со своей увеличившейся свитой на север, в сторону гор Улытау (Yesenberlin, 2015:185).

- Together with the huge caravan loaded with carpet-bags filled with coumiss (fermented mare's milk) and other victuals the khan and his increased 
retinue set out northward, to the Ulytau Hills (Yesenberlin, 2015:37).

Kumis is a traditional beverage made from mare's milk. The word was transliterated as 'coumiss'. Given the existence of a variety of other transliterations, this version is not a misspelling.

Now, let us move to the side of crafts:

- Тек босағада тұрған кісі бойындай құмыраға оқта-текте көзі түсіп кетеді де, ондағы кестелі көне нақылды ойлана оқиды (Yesenberlin, 2014:270).

- Он хмуро молчал, лишь порою рассеяно смотрел на огромный кувшин выше человеческого роста, где на древнетюркском языке было написано (Yesenberlin, 2015:96).

- He sat silent, only absently looking from time to time at a huge jug (кувшин) taller than a human being. On the jug, the following lines were written in ancient Turkic (Yesenberlin, 2015:62).

- Осы кезде қолына шылапшыны мен құманын ұстап Ораз да кірді. Үйдегілер қолдарын жуа бастады (Yesenberlin, 2014:109).

- Вернулся Ораз с кувшином и тазом для омовения рук (Yesenberlin, 2015:97).

- Oraz returned with a jug and basin for washing their hands (Yesenberlin, 2015:85).

The words 'kumyra' (1. an ornamented vessel for flowers and fruits; 2. a tall earthenware jar with a narrow neck) and 'kuman' (an oval metal vessel, often of copper or iron, with a handle, spout, and lid, used for washing of the hands and for boiling water) were translated literally: into Russian - as 'кувшин' and into English - as 'jug'. In the Kazakh language, these words describe different aspects of the same thing, but in translation, those were lost. Thus, loose translation does not deliver the specific features of a culture.

Another misunderstood word is 'shai kerpe':

- Ақ Ордаға тәжім етіп кіргеннен кейін, үш жырау хан тағының оң жағындағы шайы көрпені үстіне барып отырды (Yesenberlin, 2014:94).

- Войдя в юрту, уселись с правой стороны на стеганые шелковые одеяла (Yesenberlin, 2015:76).

- Walking inside, they settled on quilted silk blankets by the yurta's right wall (Yesenberlin, 2015:9).

The lexeme 'shai kerpe' (a sitting mattress placed on the floor, traditionally stuffed with wool) was translated as 'стеганые шелковые одеяла' and 'quilted silk blankets'. Kazakhs lay 'shai kerpe' on the floor so that guests can walk and sit with comfort. First, there was another word for shai kerpe - 'kurak kerpe' - meaning the article sewn from multi-coloured pieces of fabric. Both in Russian and English languages, however, a blanket is a flat cover made of warm material, usually used on a bed. Thus, the meaning of the word was not disclosed completely.

The unique side of each nation can be found in the national consciousness, customs and traditions. Traditions, customs and rituals are a result of a centuries-long culture, way of life, psychology, and a worldview of people. They are passed on via language from one generation to another. The worldview of the people is confined in and finds its expression via the language. Different names for some objects and things, their properties and characteristics, customs and traditions can be passed on only with linguistic units - words and phrases, idioms and proverbs, legends and tales.

In the historical trilogy, traditions and customs of the Kazakh people are widely and truthfully described. Thus, let us consider how these ethnic-specific words were translated into Russian and English.

- Демек, қазақ шежірелері Жошыны Шыңғыстың өзге балаларындай қанішер атамайды. Жыр, аңыздарда кейде қаһарымен бірге сөзге тоқтайтын, ашуын ақылға жеңгізе алатын адам етіп көрсетеді (Yesenberlin, 2014:73). 
- Даже в песнях и сказаниях народа, где всегда подчеркивается жестокость и коварство других чингизидов, о Джучи говорится в ином тоне (Yesenberlin, 2015:40).

- Even in the songs and legends of a people whose tales always emphasised the cruelty and treacherousness of the Genghizides, Juchi was told about in a different vein (Yesenberlin, 2015:71).

In Old Turkic, 'zhyry' or 'iyr' was for what people call now 'poetry'. The word is still used in many Turkic languages, such as Karakalpak, Kyrgyz, Nogay, Balkar, Karachay, Bashkir, Tatar and other languages.

The word has two meanings: 1 . in a broad sense, this is the common name for a piece of writing; 2. in a narrow sense, this is a Kazakh poem consisting of 7-8 lines. In our case, translators used the words 'песня' (Russian translation) and 'song' (English translation).

The trilogy also contains culture-specific terms describing the phenomenon known as levirate marriage, for example:

- Дәл осындай мезгілде бір күні Шағай Созақтан келген керуеншіден Дайыр қожаның баласы сүзектен қайтыс болып, жесір қалған Күнсананы «аға өлсе жеңге мұра, іні өлсе келін мұра» деген қазақтың көне дастүрі бойынша, қожаның үлкен баласына бергелі жатыр деген хабарды естіді (Yesenberlin, 2014:295).

- Но вот как-то из уст караванщика, прибывшего в Ташкент из Созака, Шагай услышал, что сын Сулейменаходжи умер от моровой язвы, а жену его Куньсану собираются по закону аменгерства - переемственности жен между родственниками передать старшему сыну правителя Созака (Yesenberlin, 2015:170).

- But Shagai heard from the mouth of a caravan driver, who had arrived in Taskent from Sozak, that the son of Suleimen-Khodzhi had died of the ulcer, and his wife Kunsan was, according to the law of the "amenger" - the succession of the wives among relatives, going to be given to the eldest son of the ruler of Sozak (Yesenberlin, 2015:206).

In Kazakhstan, there is a saying: 'When an elder brother dies - an elder brother's wife is passed down; when a younger brother does - a younger brother's wife is passed down' ('Aға өлсе жеңге мұра, іні өлсе келін мұра'). The word to define such an inheritance is 'amangerlik'. With this knowledge, translators used the strategy of transliteration and translated the given term as 'аменгерство' and 'amenger'. This translation can be called good.

Amangerlik or levirate is a type of marriage in which the brother of a deceased man is obliged to marry his brother's widow. The issue was usually discussed between blood relatives under the guidance of elders, and the marriage ceremony was carried out as prescribed by the elders. This custom had not only social and legal but also the educational and humanistic background. First, a nomadic widow could not sustain the inherited property, could not put food on the table, and could not handle other everyday problems. The groom from outside the family may be unkind to children from the first marriage. Second, other people may loot the inherited property. If so, orphans will be left without food. Third, blood relatives from the father's side could take the children from the mother if she marries a stranger.

Each citizen of Kazakhstan has to know her/his language, religion and the past because the person who tries to understand herself/himself and the people around is able to respect others. Within many centuries, Kazakhs wandered in the spacious steppe and expressed their feelings using poems and songs. They respected the words of wisdom as a source of thoughts. Even if they did not obey a sharp sword, they obeyed wise words (Karagulova et al., 2016).

Here are some of other examples:

- Қыпшақтың от ауызды, орақ тісті, қарға бойлы Қазтуған жырауы мен Арғынның ақсандақ жүйрігі, сексеннен асып кеткен, Акжол бидің әкесі 
Қотан жырау айтысады (Yesenberlin, 2014:104).

- Жырауды қошаметтеп «Уай, пәле!» деп лепіре қызынған жұрт тына қалды (Yesenberlin, 2015:98).

- Только и разговоров было, что о предстоящем состязании известных всей степи певцов-сказителей: кипчака Казтуган-жырау с аргынским импровизатором Котанжырау, отиом самого Акжол-бия (Yesenberlin, 2015:73).

- Собравшиеся, которые до сих пор подзадоривали певца бодрыми криками "Ой, пале!", сразу осеклись и затихли, как ударившееся о воду пламя (Yesenberlin, 2015:100).
- The talks were focused on the coming contest of narrator-songsters: the Kipchak Kaztugan-Zhyrau with the Argyn improviser Kotan-Zhyrau, the father of Akzhol-Biy himself (Yesenberlin, 2015:137).

- Those around who had been encouraging the singer with their cheerful "Come on! Hot it up!" cut themselves short immediately and quietened down like fire does when it clashes with water (Yesenberlin, 2015:202).

The word 'zhyrau' was translated literally as 'певеи' and 'singer. However, the Kazakh word and translations do not share the same meaning.

\begin{tabular}{|c|c|c|}
\hline & & \\
\hline $\begin{array}{l}\text { Zhyrau (Kazakh: } \\
\text { Жыpay)-a folk teller, } \\
\text { a } \\
\text { performing his own } \\
\text { songs }\end{array}$ & $\begin{array}{l}\text { Певец (Russian: } \\
\text { pevets) - a person, } \\
\text { who knows how to } \\
\text { sing; an artist, who } \\
\text { does the signing. }\end{array}$ & $\begin{array}{l}\text { Singer - a person who sings, especially one } \\
\text { who earns a living by singing } \\
\text { [http://www.thefreedictionary.com/singer]. }\end{array}$ \\
\hline
\end{tabular}

Thus, one can notice that translations lack an ethnic tone.

Below is more:

- Керуен сарайлар, қала аулалары әнкүйлі, ойын-күлкілі думанға толып, екі жақтың әскерлері бейбіт басекеге шығып, ар жерде сайыс, күрес, көкпар, жамбы ату ойындарына кіріскен (Yesenberlin, 2014:300).

- Из всех караван-сараев и подворий неслись звуки труб и барабанов. А на свободных площадках уже происходили состязания борцов, неизменные конные игры $c$ козлодранием, стрельбы из лука по мешочкам с золотом и серебром (Yesenberlin, 2015: 220).

- The sounds of horns and drums could be heard coming from all the inns and caravanserais. And on the squares, wrestling competition, games on horseback, and the shooting of arrows into bags of gold and silver were already taking place (Yesenberlin, 2015:64).

The words 'kokpar' (a sport where two teams of horse riders grapple over a decapitated goat, which they try to deposit) and 'zhamby atu' (a competition amongst men where the goal is to knock down a heavy silver disc, called a zhamby, hanging from a thin rope, with a bow and arrow) are absent in other languages. They are traditional Kazakh sports. In translations, these peculiarities were preserved descriptively. Other examples of good descriptive translation are below:

- Бірі - көне Қыпшақтарда өлген адамда жаназалағанда, не жетісін, қырқын, асын бергенде оның бейнесіне сәйкестей ағаштан қуыршақ ойып, үстіне бұрынғы киімдерін кигізіп, өздерінің ортасына отырғызатын дастүр болған (Yesenberlin, 2014:143). 
- Одна из них гласит, что некогда был обычай у кипчаков, по которому на седьмой и на сороковой день после смерти достойного человека изготовляют из дерева куклу, во всем похожую на покойного, надевают на него парадные одежды, любимые им при жизни, и сажают в круг пирующих (Yesenberlin, 2015:194).

- One of them says that the Kipchaks once had a custom according to which on the seventh and fortieth day after the death of a worthy man a dummy was made from wood which was very much like the deceased one (Yesenberlin, 2015:54).

- Unfortunately, translations lost somewhat in an idiomatic narrative. For example, the following phrase cannot be translated word for word, as it specific to Kazakh mentality:

- Екі қошқардың басы бір қазанға сыя Ma? (Yesenberlin, 2014:62).

- В одном котле невозможно варить головы сразу двух баранов (Yesenberlin, 2015:208).

- It is impossible to boil two sheep's heads in one and the same pot (Yesenberlin, 2015: 445).

Below is another example:

- Хан аулы маңында мал болмағанмен, төменгі елдің қайтқан қойының маңырағаны, құрақтағы жылқысының кісінегені, аусыл аруаналардың боздағаны, зеңгі баба шаңырақ мүйіз сиырлардың мөңірегені алыстан естіліп жатты (Yesenberlin, 2014:102).

- Обычные мирные звуки раздавались в теплом воздухе: блеяли где-то неподалеку овцы, мычали проходящие мимо коровы с огромными рогами и тяжелым выменем, предком которых, как говорят, был сказочный бык Зеги-Баба (Yesenberlin, 2015:274).

- The ordinary peaceful sounds were heard in the warm peaceful air: the bleating of sheep, the mooing of huge-horned and heavy-uddered cows with their ancestors allegedly being the fabulous bull ZeghiBaba (Yesenberlin, 2015).

In Kazakhstan, protectors of domestic animals had their own mythological names: horse's name was Kambar Ata, camel's - Oisyl Kara, cow's - Zengi Baba, and sheep's - Shopan Ata (Zhanuzakov, 2008). The Kazakhs believed that these four protectors were holding four parts of the world and turned to them with a request to fulfil one's desires. In this case, transliteration is the method of choice. Nevertheless, transliteration requires an additional clarification in the footnote below for full immersion of the reader into the world depicted in the book.

Kazakhs, like other nations, arranged a system of government that fits with their time. Therefore, any position was evaluated under the rules of governing, respect, responsibility and commitment to people.

The common lexical heritage of Turkic peoples has a group of words conveying meanings of names and positions related to society, tribe, Khanate, and government.

- Ұлы мәртебелі, әлем әміршісі, хан қандай болу керек (Yesenberlin, 2014:176).

- Скажи, о обладатель великой славы и покоритель вселенной, каким должен быть подлинный хан (Yesenberlin, 2015).

- Pray tell me, o Possessor of Great Glory and Conqueror of the Universe, what kind of human is a true khan supposed to be? (Yesenberlin, 2015:184).

The translator translated the word 'khan' using the transliteration method. Kurbangaly (1999) notes:

The title 'khan' was first used by the Mongols, then by the Persians and other Turkic peoples to name a particular ruler. Kazakhs say 'kan' (blood) because when Shyngys was born, a handful of blood flowed. Later the children used this word for pride. Later it became commonplace to refer as 'khan' to people of simple origin. In fact, it is believed that Khan is a 
person who spills blood. Akim, who does not give the order to kill people, is not called a khan. However, one cannot tell that the word ' $k a n^{\prime}$ originates from the time of Shyngys. The story says that the Mongols used this title before that (Kurbangaly, 1999:204).

- Бұлар жүреміз деп атқа қонғалы тұрғанда, ордаға қос атты шабарман келді (Yesenberlin, 2014:48).

- Подскакавший гонец - шабарман свалился с коня (Yesenberlin, 2015:96).

- A messenger, a shabarman, dropped from his horse (Yesenberlin, 2015:73).

Because in both translations, the word 'shabarman' was translated using two methods at a time - transliteration and word replacement - a new word was created. To disclose the meaning of the unknown word and introduce the underlying words, translators delved into heuristic studies (establishing connections between two languages through the simultaneous activations of related words in both languages). For example, Turks recognise the words 'atarman' and 'shabarman' by the affixes 'atar' and 'shabar', while English people recognise them by the affixes 'man' and 'men' (businessman).

- Шыңғысхан он адам бір адамға бағынсын деп бұйырған(біздіңше оны онбасы дейді), ал ол онбасы бір жүзбасыға бас иген. Он жүзбасының үстінен бір адам қараған. Оны мыңбасы деген. Бар әскерінің басына үш ноян қойған. Бұл үш ноян барып, бір Қолбасшыға тізе бүккен (Yesenberlin, 2014:102).

- По высочайшему установлению Чингисхана десять воинов подчиняются одному десятнику онбасы, а десять онбасы - одному сотнику - жузбасы. Над десятью жузбасы возвышается один мынбасы, а во главе десяти тысячников - мынбасы - один темник. Всеми войсками командует два или три нойона. Все они подчиняются главнокомандующему (Yesenberlin, 2015:109).

- As concerns the Mongol host. Following the highest decree of Genghiz Khan, ten warriors shall be subordinate to one charge-hand, onbasy, and ten onbasys to one lieutenant, that is a zhunbasy. One mynbasy is superior to ten zhunbasies, and at the head of ten mynbasies is one temnik. All the troops are to be commanded by two or three noyons. All of them shall be subordinate to a commander-in-chief (Yesenberlin, 2015:146).

- Transliteration was applied to words, such as 'onbasy' (foreman), 'zhunbasy' (unit commander), 'mynbasy' (group commander), 'noyon' (lord), but the word 'kolbassy' was translated by using the similar words 'главнокомандующий' and 'commander-in-chief'.

The last example is the word 'aksakal':

- Осындай шешімге келген ақсақалдар өздерінің көштеріне қарай беттеді (Yesenberlin, 2014).

- Аксакалы отправились по своим караванам (Yesenberlin, 2015:98).

- The aksakals went to their caravans (Yesenberlin, 2015:107).

Aksakal was a highly respected leader of the clan to whom people came for advice and parting words. The analogue 'an old man' is not sufficient. The translation has to evoke the same emotions and feelings in readers as the original test does evoke in the narrator. Sideshova (2018) believes that it would be appropriate to provide a link or use descriptive translation. This method of translation makes the word stand out so that the reader immediately recognises the translation. Besides, such a word becomes expressive in an emotional sense.

\section{Conclusion}

Because the translation is the universal way of communication between people, it is a special kind of cultural connections. The translation expands the reader's outlook, familiarises him 
with the customs and traditions of other nations, teaches to treat a different culture respectfully, and puts onto display the national peculiarities of culture, history, ethnography, and geography of other nations.

Language and Culture are interrelated. Any culture evolves from ethnicity and always has its footprint in language.

This research resulted in a collection of hundred culturally-bound words found in I. Yesenberlin's historical trilogy 'The Nomads'. The analysis of these words leads to the following conclusions. Transliteration is the primary way to translate general ethnographic realia into Russian. The second translation method that is often used is the equivalent translation (using words with meanings that are similar to the meanings of the original words). Additionally, translators may create a calque or new words and phrases. A descriptive translation was used to convey the peculiarities of the original words because transliterated realia of the Kazakh language are hard to understand. The equivalent translation of some culture-specific words is shadeless and unclear (kymura - jug; kylysh, semser, aldaspan - sabre, etc.). English translation lost the meaning of many culture-specific words; some of them were not translated at all.

\section{References}

Abildinova, Z. (2015). The concept of ethnos in the linguistic worldview. GISAP: Philological Sciences, (6).

Agorni, M. (2016). Tourism across languages and cultures: accessibility through Translation. Cultus, 13.

Akhmanova, O.S. (2004). The Glossary of Linguistic Terms. Editorial URSS, Moscow, pp. 571.

Al-Rikaby, A. B. M., Mahadi, T. S. T., Lin, A., \& Tan, D. (2018). Domestication and Foreignization Strategies in Two Arabic Translations of Marlowe's Doctor Faustus: Culturally bound Terms and Proper Names. Pertanika Journal of Social Sciences \& Humanities, 26(2).
Atabaeva, M.S. (2006). The ethno-linguistic basis of dialectical Kazakh lexicon. Almaty, pp. 284.

Bahnova, Y. A. (2017). O. Wilde's" The Harlot's House" Translated by Fyodor Sologub: Style and Concept Features of The Translated Text. Tomsk State University Journal, 423, 15-19.

Barkhudarov, L.S. (1975). Language and translation. Mezhdunarodnyye Otnosheniya Publishing House, Moscow, pp. 190.

Bassnett, S. (2013). Translation. Routledge.

Cronin, M. (2013). Translation and globalisation. Routledge.

Davier, L., \& Van Doorslaer, L. (2018).

Translation without a source text:

methodological issues in news

translation. Across Languages and

Cultures, 19(2), 241-257.

Fedorov, A.V. (2002). The fundamentals of the general theory of translation: linguistic problems. Moscow, pp. 416.

Geisinger, K. F. (1994). Cross-cultural normative assessment: Translation and adaptation issues influencing the normative interpretation of assessment instruments. Psychological assessment, 6(4), pp. 304.

Karagulova, B., A. Kushkimbayeva, K. Sadirova, S. Mukhtarov, N. Saduakas and A. Trusheva (2016). The Linguocultural Nature of the Turkic Metrological Names. Man In India, 96 (7), pp. 2267-2281.

Karagulova, B., A. Kushkimbayeva, S. Kurmanbayeva, A. Alim Khan and Z. Kaiyrbaeva (2016). Linguocultural Description and Formation of Archaic Words. Indian Journal of Science and Technology, 9(14).

Khaidar, A. (1998). The recent problems of the Kazakh language. Almaty: Ana Tili Publishing House, pp. 304.

Kopylenko, M.M. (1995). The Basics of Ethnolinguistics. Almaty, pp. 228.

Kroeber, A. L., \& Kluckhohn, C. (1952). Culture: A critical review of concepts and 
definitions. Papers. Peabody Museum of Archaeology \& Ethnology, Harvard University.

Kurbangaly, Kh. (1999). Tawarikh Hamza. Almaty, pp. 288.

Kurkebaev, K.K. (2013). Spiritual and Material Culture in the Kazakh Language: A Textbook. Almaty: Kazakh University, pp. 191.

Lefevere, A. (2016). Translation, rewriting, and the manipulation of literary fame. Routledge.

Mankeeva, J. M. (2008). Cognitive backgroud of ethnic names in the Kazakh language. Almaty, pp. 356.

Maslova, V.A. (2001). Cultural Linguistics: A University Textbook. Academia Publishing House, pp. 208.

Meylaerts, R. (2010). Multilingualism and translation. Handbook of translation studies, 1, pp. 227-230.

Mukhtarova, S.S. (2017). Comparative analysis of culture-speific everyday vocabulary from the I. Yesenberlin's trilogy "The Nomads". Bulletin of the Bashkir University, 22(4), pp. 1175-1178.

Repin, B.I. (1970). National-specific realia words as a special part of vocabulary in the translated writing. Theoretical and practical issues of teaching foreign languages: Collection of scientific works. Moscow, pp. 98.

Sideshova, Z.G. (2018). On the problem of translation of Kazakh words of the lexicosemantic group "Social affiliation" into English and Russian languages (on the materials of "The shot on the mountain pass" by M. Auezov). Bulletin of Bashkir University, 23(1), pp. 107110.

Venuti, L. (2017). The translator's invisibility: A history of translation. Routledge.
Vereshchagin, E.M. and V.G. Kostomarov (1980). Linguistic theory of words. Russkiy Yazyk Publishing House, Moscow, pp. 320.

Vinogradov, V.S. (2001). Introduction to Translation. General and Lexical Issues. IOSO RAO Publishers, Moscow, pp. 224.

Vlahov, S.I. ans S.P. Florin (2006). Untranslatable in translation. Moscow, pp. 448.

Yesenberlin, I. (2014). Көшпенділер. Ilys Yesenberlin. Almaty: «Көшпенділер» баспасы, pp. 896.

Yesenberlin, I. (2015). The Nomads. Russian translation by M. Simashko. Almaty: Association of Publishers, Printers and Book Distributors. Book 1: The Charmed Sword, pp. 376.

Yesenberlin, I. (2015). The Nomads. Russian translation by M. Simashko. Almaty: Association of Publishers, Printers and Book Distributors. Book 2: Despair, pp. 380.

Yesenberlin, I. (2015). The Nomads. Russian translation by M. Simashko. Almaty: Association of Publishers, Printers and Booksellers. Book 3: Khan Kene, pp. 380.

Yesenberlin, I. (2015). The Nomads: a noveltrilogy. English translation by O. Chorakaev. Almaty: Association of Publishers, Printers and Book Distributors. Book 1: The Charmed Sword, pp. 380.

Yesenberlin, I. (2015). The Nomads: a noveltrilogy. English translation by O.Chorakaev. Association of Publishers, Printers and Book Distributors. Book 2: Despair, pp. 380.

Yesenberlin, I. (2015). The Nomads: a noveltrilogy. English translation by O. Chorakaev. Almaty: Association of Publishers, Printers and Booksellers. Book 3: Khan Kene, pp. 380.

Zhanuzakov, T. (2008). The Kazakh Dictionary. Almaty: Dayk-Press, pp. 986. 